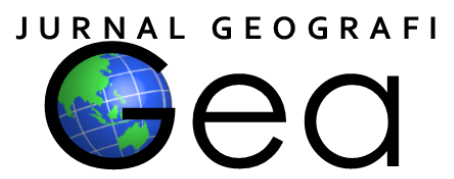

\title{
KONTRIBUSI MATA PELAJARAN GEOGRAFI UNTUK MENINGKATKAN SEMANGAT BELA NEGARA SISWA SMA DI PROVINSI ACEH
}

\author{
Ahmad Nubli Gadeng ${ }^{1}$, Epon Ningrum ${ }^{2}$, Abdul Wahab Abdi ${ }^{3}$, Daska Aziz ${ }^{4}$, Mirza Desfandi ${ }^{5}$ \\ ${ }^{1345}$ Program Studi Pendidikan Geografi, Universitas Syiah Kuala \\ ${ }^{2}$ Departemen Pendidikan Geografi, Universitas Pendidikan Indonesia \\ 1ahmadnubli@unsyiah.ac.id
}

\begin{abstract}
The purpose of this study is to find out how the contribution of geography in order to increase the spirit of defending the country in high school students in Aceh Province. The research method used in this article is descriptive qualitative, and studies of literature (literature studies) from various sources such as books, journals, laws and regulations in the form of print media / online media) used in data collection in this study. Finally, the data analysis technique in this study uses the Delphi method. The results obtained from this study are: the spirit of defending the country is a program that is being intensely promoted by the government today, defending the country can be carried out by all people in accordance with their respective categories and age. For example through learning in high school, one of them on the subject of Geography there is a discussion of material that can arouse students' interest to maintain / defend the integrity of the country. So that the role of the geography teacher is very strategic in increasing the spirit of defending the country, and it is also hoped that student awareness through the internalization process is considered successful, and will have a positive impact on the integrity of the Indonesian State. Finally, it is hoped that the government can make geography a compulsory subject for students in Indonesia, this is because the subject of Geography is very strategic in increasing the spirit of defending the country to high school students.
\end{abstract}

Keywords: Geography Subjects, National Defending Spirit

\begin{abstract}
ABSTRAK
Tujuan dari penelitian ini yaitu untuk mengetahui bagaimana kontribusi dari mata pelajaran geografi dalam rangka meningkatkan semangat bela negara pada siswa SMA di Provinsi Aceh. Metode penelitian yang digunakan dalam artikel ini yaitu deskriptif kualitatif, dan studi literatur (studi kepustakaan) dari berbagai sumber seperti buku, jurnal, peraturan perundang-undangan dan surat kabar berupa media cetak/media online yang digunakan dalam pengumpulan data pada penelitian ini. Terakhir, teknik analisis data dalam penelitian ini menggunakan metode delphi. Adapun hasil yang diperoleh dari penelitian ini yaitu: semangat bela negara merupakan program yang sedang gencarnya digalakkan oleh pemerintah dewasa ini, bela negara dapat dilakukan oleh seluruh masyarakat sesuai dengan kategori dan usianya masing-masing. Sebagai contoh melalui pembelajaran di SMA, salah satunya pada MAPEL Geografi terdapat pembahasan tentang materi yang dapat menggugah minat siswa untuk menjaga/membela keutuhan negara. Sehingga peran guru geografi sangat strategis dalam meningkatkan semangat bela negara, dan diharapkan pula kesadaran siswa melalui proses internalisasi dikategorikan berhasil, serta berdampak positif terhadap keutuhan Negara Indonesia. Terakhir, diharapkan agar pemerintah dapat menjadikan geografi sebagai mata pelajaran wajib
\end{abstract}


untuk peserta didik di Indonesia, hal ini dikarenakan MAPEL Geografi sangat strategis dalam meningkatkan semangat bela negara pada siswa SMA.

Kata kunci: Mata Pelajaran Geografi, Semangat Bela Negara

\section{PENDAHULUAN}

Bela negara merupakan program yang sedang gencarnya dilakukan oleh pemerintahan masa Jokowi-JK dan JokowiMa'ruf. Gerakan nasional bela negara yang dideklarasikan oleh Presiden Republik Indonesia pada tanggal 19 Desember 2014 lalu (Putra, 2015 dalam Maruapey, 2016: 88). Sebagai tindak lanjut dari kegiatan presiden, dicanangkan kembali program bela negara oleh menteri pertahanan Republik Indonesia, Ryamizard Ryacudu pada tahun 2015 lalu (Maharani, 2015 dalam Maruapey, 2016: 88). Sejak dari 2014 sampai 2020 kegiatan bela negara sangat sering digaungkan oleh pemerintah dan didengar oleh masyarakat melalui berbagai media seperti televisi, radio dan surat kabar (cetak dan online) lainnya.

Bela negara memiliki tujuan utama yaitu untuk melindungi, menjaga, mempertahankan keutuhan suatu negara, dalam hal ini keutuhan NKRI. Sebagaimana yang dikemukakan oleh menteri pertahanan Republik Indonesia, Ryamizard Ryacudu menegaskan, kegiatan bela negara bertujuan mewujudkan pembina kader bela negara yang bisa membangun kesadaran bela negara dan mampu mengaplikasikan dalam kehidupan sehari-hari selanjutnya mampu menyosialisasikannya ke orang lain (Maharani, 2015 dalam Republika). Kemudian, Prabowo Subianto juga mengatakan "program bela negara yang disampaikan menteri pertahanan Ryamizard Ryacudu dinilai penting" (Maharani, 2015 dalam Republika). Wakil Ketua Majelis Permusyawaratan Rakyat Republik Indonesia (MPR RI) Hidayat Nur Wahid juga menyampaikan pandangan berupa "kesadaran bela negara penting untuk ditanamkan, ini sebagai landasan sikap dan perilaku bangsa Indonesia". (Amanda, 2017 dalam Republika). Sehingga berdasarkan beberapa pendapat yang disampaikan oleh para petinggi negara maka dapat disimpulkan membuat bela negara sangat penting dilakukan oleh seluruh masyarakat yang berada di Indonesia.
Berbagai pendapat tentang urgensi diadakannya bela negara di atas, ternyata berangkat dari berbagai kekhawatiran terhadap kepedulian masyarakat akan semangat bela negara dan rasa cinta tanah air yang dimiliki oleh masyarakat Indonesia selama ini. kekhawatiran yang dialami oleh pemerintahan selama ini benar terjadi dalam masyarakat, hal yang sangat mengejutkan dikemukakan oleh menteri pertahanan Republik Indonesia, Ryamizard Ryacudu "wawasan kebangsaan atau bela negara bangsa Indonesia terlalu rendah, berdasarkan survei masalah wawasan kebangsaan yang dilakukan di 106 negara, Indonesia menempati urutan ke-95, ini rendah sekali” (Maharani, 2015 dalam Republika). Kemudian, Hadi dkk (2014:211) Rasa nasionalisme yang diwujudkan dengan sikap bela negara mulai memudar, seakan-akan bela negara hanya menjadi beban tugas militer, unsur-unsur bela negara kurang terimplementasikan dalam kehidupan masyarakat Indonesia, terlebih lagi kaum muda semakin banyak yang kurang paham dan kurang menjiwai terhadap permasalahan bela negara.

Masyarakat sudah mulai acuh tak acuh terhadap keutuhan NKRI, sehingga berdampak terhadap rasa nasionalisme masyarakat mengalami kemunduran yang sudah berada pada taraf sangat mengkhawatirkan. Rendahnya semangat bela negara seperti yang dikemukakan di atas, sebagai suatu akibat yang terjadi dari berbagai permasalahan yang berada di dalam masyarakat sejak awal kemerdekaan Indonesia pada tahun 1945 sampai saat ini (2020). Hadi dkk. (2014:211) Perkembangan sosial yang begitu cepat menyebabkan sikap rasa cinta tanah air, jiwa patriotisme dan nasionalisme menjadi berkurang, kondisi ini terjadi karena sistem penanaman nilai-nilai sejarah perjuangan belum optimal.

Hal yang sama juga dialami di Provinsi Aceh, sebagai salah satu dari 34 provinsi yang terdapat di Negara Kesatuan Republik Indonesia dan terletak di bagian ujung barat Indonesia. Rasa nasionalisme yang mulai 
memudar sehingga berdampak terhadap kurangnya semangat masyarakat dalam partisipasi bela negara. Permasalahan tersebut disebabkan oleh berbagai faktor, salah satunya yaitu akibat konflik yang berkepanjangan terjadi di Provinsi Aceh dan berakhir pada 15 Agustus 2005 silam. Senada dengan hasil penelitian Jayanti (2010:71) Akibat konflik yang berkepanjangan selama hampir 30 (tiga puluh) tahun telah menghancurkan seluruh sendi kehidupan masyarakat Aceh dan mengakibatkan hancurnya dunia pendidikan, hilangnya kesempatan kerja, akitivitas ekonomi rakyat tidak berjalan dengan baik dan berkurangnya nilai-nilai nasionalisme masyarakat Aceh. Dalam menyelesaikan permasalahan rendahnya semangat bela negara yang terjadi di Indonesia dan khususnya di Provinsi Aceh, pemerintah perlu melakukan berbagai cara dan tindakan-tindakan penting. Mengingat, tindakan bela negara dapat dilakukan pada berbagai jenjang dan berbagai usia mulai dari sejak dini (masa anak-anak) sampai usia tua (tanpa batasan yang ditetapkan) selama masih menjadi WNI.

Salah satu tindakan yang dapat dilakukan dalam rangka meningkatkan semangat bela negara yaitu melalui dunia pendidikan yang dipelopori oleh guru kepada sasarannya yaitu siswa mulai dari tingkatan PAUD, TK, SD/MI, SMP/MTs dan SMA/SMK/MA. Melalui pembelajaran yang terdapat pada berbagai mata pelajaran di sekolah, selama ini pemerintah hanya mengetahui jikalau hanya mata pelajaran PKn (Pendidikan Kewarganegaraan) yang dianggap dapat meningkatkan rasa cinta tanah air. Akan tetapi, penulis memiliki asumsi berupa dalam rangka menyelesaikan permasalahan rendahnya semangat bela negara dan rasa cinta tanah air dapat dilakukan melalui mata pelajaran geografi pada tingkatan SMA//SMK/MA. Oleh karena itu, membuat penulis tertarik untuk mengangkat judul tentang kontribusi mata pelajaran geografi dalam meningkatkan semangat bela negara siswa SMA di Provinsi Aceh". Selanjutnya, untuk mengetahui dan menganalisis secara mendalam bagaimana kontribusi mata pelajaran geografi dalam meningkatkan semangat bela negara siswa SMA di Provinsi Aceh.

\section{METODE PENELITIAN}

Metode penelitian yang digunakan dalam penelitian ini yaitu deskriptif kualitatif yang akan dituangkan dalam bentuk uraian kata-kata untuk menjawab bagaimana kontribusi mata pelajaran geografi dalam meningkatkan semangat bela negara siswa SMA di Provinsi Aceh. Teknik pengumpulan data yang digunakan yaitu studi literatur (studi kepustakaan) yang memiliki kaitan dengan tema pembahasan, bersumber dari berbagai buku, jurnal, peraturan perundang-undangan dan surat kabar berupa media cetak/media online) lainnya. Teknik analisis data dalam penelitian ini menggunakan metode delphi, hal ini dikarenakan hasil dari penelitian akan didiskusikan kembali dengan berbagai ahli pada bidangnya, dalam hal ini ahli yang menjadi rujukan yaitu ahli dalam bidang ilmu geografi dan ilmu PKn (Pendidikan Kewarganegaraan), untuk membuktikan sudah sesuai atau belum analisis yang dilakukan dalam penelitian ini.

\section{HASIL DAN PEMBAHASAN \\ Bela Negara}

Bela negara merupakan suatu sikap yang diperlihatkan dan dibuktikan oleh warga negara sebagai bukti akan kecintaan terhadap suatu negara, bentuk kecintaan dapat dibuktikan melalui berbagai wujud dalam rangka melindungi, menjaga dan mempertahankan keutuhan suatu negara, dari serangan atau ancaman baik itu yang datang dari negara lain maupun dari dalam negeri sendiri. Basrie (1998:8) Bela negara adalah tekad, sikap dan tindakan warga negara yang teratur, menyeluruh, terpadu dan berlanjut yang dilandasi oleh kecintaan pada tanah air, kesadaran berbangsa dan bernegara Indonesia, keyakinan akan kesaktian Pancasila sebagai ideologi negara, kerelaan untuk berkorban guna meniadakan setiap ancaman baik dari luar maupun dari dalam negeri yang membahayakan kemerdekaan dan kedaulatan negara, kesatuan dan persatuan bangsa, keutuhan wilayah dan yurisdiksi nasional, serta nilai-nilai Pancasila dan UUD 1945.

Kemudian, bela negara merupakan sikap setiap individu dengan dijiwai oleh kecintaannya kepada NKRI, serta semangat kejuangan pantang menyerah dalam jiwa Sapta 
Marga, dilandasi keimanan dan ketaqwaan sesuai dengan Pancasila dan UUD 1945, berniat tekad bulat tanpa pamrih dan berani rela berkorban melaksanakan bela negara dengan didasari sikap profesionalitas dan integritasnya untuk bersama-sama mencapai tujuan negara yang aman dalam menjamin kelangsungan hidup bangsa dan negara (Yulianto, 2013:365; Maruapey, 2016: 88). Sutarman (2011:77) Pembelaan negara atau bela negara adalah tekad, sikap dan tindakan warga negara yang teratur, menyeluruh, terpadu dilandasi oleh kecintaan pada tanah air, kesadaran berbangsa dan bernegara Indonesia, keyakinan akan kesaktian Pancasila sebagai ideologi negara, dan kerelaan untuk berkorban guna meniadakan setiap ancaman baik dari luar maupun dalam negeri yang membahayakan kemerdekaan dan kedaulatan negara.

Inti dari bela negara yang terdapat di Indonesia yaitu mempertahankan kemerdekaan Indonesia yang sudah susah payah direbut oleh pahlawan, kemudian menjaga keutuhan Negara Kesatuan Republik Indonesia (NKRI) dari Sabang sampai Merauke, dari Pulau Talaud sampai Pulau Rote. Serta melindungi NKRI dari berbagai ancaman dan serangan baik itu yang datang dari negeri lain maupun dari dalam negeri. Kegiatan bela negara sangat penting dibangkitkan kembali dewasa ini, hal ini dikarenakan kestabilan keamanan yang mulai terganggu, disebabkan adanya pihak-pihak lain baik yang berasal dari luar negeri maupun dari dalam negeri, yang ingin menggoyangkan kemerdekaan dan kedaulatan Indonesia, serta ingin menguasai Indonesia.

Lesmana (2016) Ada pihak yang meragukan keberhasilan internalisasi nilainilai bela negara, sejak 20 tahun terakhir Indonesia dicekoki habis-habisan oleh nilainilai destruktif yang sebagian berasal dari budaya luar, jika tidak ada yang berani melakukan gerakan nasional merevitalisasi nilai-nilai Sumpah Pemuda, Indonesia hampir dipastikan akan semakin terpuruk. Oleh karena itu, kita selaku generasi muda harus peka dan dapat membaca sejak dini gerak-gerik yang mencurigakan tersebut, jangan sampai negara Indonesia dijajah kembali oleh negara luar, sangat tidak diharapkan warga Negara Indonesia menjadi budak di negara sendiri.

Pada umumnya, bela negara dapat dibagi menjadi dua dimensi besar. Sebagaimana yang dikemukakan Saifuddin (2016) Pertama, dimensi yang nyata, bersifat fisik dan tindakan terhadap ancaman/serangan atas kedaulatan bangsa dan negara, dimensi ini kerapkali dilekatkan pada perjuangan fisik mempertahankan kedaulatan negara dan bangsa yang biasa disebut sisi militer bela negara; Dimensi pertama lebih identik dengan peran, tugas dan fungsi dari militer. Dan bahkan saat ini pemerintah juga sedang gencar-gencarnya melatih dan membentuk kader-kader bela negara, sebagaimana yang dikemukakan menteri pertahanan Republik Indonesia, Ryamizard Ryacudu (Maharani, 2015 dalam Republika): Ada lima hal yang ditekankan dalam pembentukan kader bela negara, yakni cinta kepada tanah air, rela berkorban untuk nusa dan bangsa, yakin akan kebenaran ideologi Pancasila, sadar bebangsa dan bernegara, serta memiliki kemampuan awal bela negara. Selain itu, sasaran pembentukan bela negara adalah tercapainya pembina bela negara yang memiliki kepemimpinan dan disiplin yang baik, berkepribadian dalam berbudaya dan mampu bekerja sama dalam bentuk tim.

Pembentukan kader bela negara sebagai wujud pengantisipasian pada saat keadaan genting dan negara mengalami kekurangan pasukan yang dibutuhkan untuk membantu anggota militer di medan pertempuran, sehingga diharapkan kader inilah yang dapat menjadi pasukan cadangan sewaktu-waktu dibutuhkan oleh negara dalam rangka mempertahankan kemerdekaan dan menjaga keutuhan NKRI. Kemudian, Saifuddin (2016) Dimensi Kedua yaitu proses penanaman dan pengejawantahan pengetahuan, keyakinan, dan nilai cinta tanah air yang tidak bersifat fisik melainkan abstrak namun berada di dalam benak yang mendalam setiap warga negara, dimensi yang kerapkali disebut juga sisi non-militer bela negara ini biasanya tidak nyata karena tersimpan dalam alam pikiran warga bangsa, tetapi bilamana bangsa berada dalam suatu konteks yang relevan, misalnya hadirnya ancaman terhadap eksistensi bangsa dan negara, maka keyakinan 
dan nilai cinta tanah air itu akan digugah dan diaktifkan untuk membela.

Pada dimensi kedua inilah, bukti konkret yang menunjukkan bahwa kegiatan bela negara dapat dilakukan oleh siapa saja, kapan saja dan di mana saja tanpa ada batasannya, selama jiwa dan raganya masih mencintai NKRI. Berbagai cara dapat dilakukan oleh masyarakat dalam rangka pelaksanaan program bela negara. Keikutsertaan warga negara dalam upaya bela negara diselenggarakan melalui: (a) Pendidikan Kewarganegaraan; (b) Pelatihan dasar kemiliteran secara wajib; (c) Pengadilan sebagai prajurit Tentara Nasional Indonesia secara sukarela dan secara wajib; (d) Pengabdian sesuai dengan profesi (Maruapey, 2016: 88). Jadi, intinya kegiatan bela negara dapat juga dilakukan dalam dunia pendidikan, militer, perekonomian dan berbagai instansi dan sektor serta profesi-profesi lainnya yang terdapat di dalam masyarakat. Tippe (2013:423) Nilai-nilai bela negara itu, harus dimiliki dan dilakukan semua warga negara Indonesia dalam kehidupannya sehari-hari.

Pada akhirnya, apabila berbagai tindakan sebagaimana yang telah disebutkan di atas sudah terlaksana dengan baik di dalam masyarakat, maka secara tidak langsung warga negara Indonesia sudah melaksanakan dengan baik sesuai amanah para leluhur bangsa sebagaimana yang dipesankan dalam Pasal 27 ayat 3 UUD 1945, yang berbunyi bahwa usaha bela negara merupakan hak dan kewajiban setiap warga negara. Hasil dari kegiatan bela negara yaitu meningkatkan rasa nasionalisme masyarakat yang tinggi. Nasionalisme adalah tekat atau semangat dari setiap warga negara untuk menjaga dan mempertahankan bangsa dan negaranya agar selalu meningkat rasa kenyamanan, keamanan dan kesejahteraannya serta terjamin kedaulatannya (Hardjosatoto, 1985:42). Dan juga menjadikan masyarakat Indonesia memiliki jiwa patriotisme yang baik. Hal ini dikarenakan masyarakat Indonesia selama ini (75 tahun) sudah mempertahankan kemerdekaan, menjaga keutuhan NKRI dan melindungi NKRI dari berbagai ancaman dan serangan yang datang dari berbagai sisi, baik dari luar maupun dalam negeri.

\section{Kontribusi Mata Pelajaran Geografi dalam Meningkatkan Semangat Bela Negara}

Salah satu kegiatan bela negara yang dapat dilakukan yaitu melalui bidang pendidikan. Sebelum membahas secara mendalam tentang kontribusi mata pelajaran geografi dalam meningkatkan semangat bela negara pada siswa SMA, maka alangkah baiknya jikalau penulis membahas terlebih dahulu tentang urgensi (peranan) pendidikan dalam kegiatan bela negara. Hal ini dikarenakan mata pelajaran geografi berada di dalam ranah pendidikan. Pendidikan sebagai salah satu cara ampuh dalam meningkatkan semangat bela negara pada siswa mulai dari jenjang PAUD, SD/MI, SMP/MTs dan SMA/MA. Saifuddin (2016) Bela negara paling tepat diinteralisasikan melalui proses pendidikan, yaitu sebagai proses transmisi kebudayaan, atau proses belajar kebudayaan, tak dapat disangkal pendidikan memegang peranan kunci dalam menanamkan pengetahuan tentang kebangsaan dan cinta tanah air sejak usia dini, semua bangsa di dunia memanfaatkan wahana pendidikan untuk menumbuhkan rasa cinta tanah air, bangsa, dan bela negara dengan berbagai model dan metode.

Pendidikan sebagai salah satu komponen penting yang harus dipersiapkan dengan baik, untuk kesuksesan di masa depan suatu negara. Pendidikan memiliki tujuan dan fungsinya masing-masing. Thoha (2004:1) Tujuan pendidikan adalah menciptakan seseorang berkualitas, berkarakter dan memiliki pandangan yang luas ke depan untuk mencapai suatu cita-cita yang diharapkan serta mampu beradaptasi secara cepat dan tepat di dalam berbagai lingkungan. Kemudian, fungsi pendidikan salah satunya adalah sebagai media penanaman nilai, khususnya mengenai filosofi pendidikan dengan pendekatan sistem-sistem formal, guru adalah pencipta lingkungan pendidikan siswa dan merupakan sumber ilham bagi siswa (Yulianto, 2013:214).

Oleh karena itu, melalui internalisasi (penanaman nilai-nilai) yang terdapat di dalam pendidikan, dapat membentuk karakter siswa seperti yang diharapkan bersama (dalam hal ini diharapkan dapat membentuk karakter siswa yang memiliki semangat tinggi dalam konteks bela negara dan rasa cinta tanah air). Salah satu 
negara di dunia yang sudah berhasil menanamkan nilai-nilai bela negara dan patriotisme adalah Jepang. Sebagai contoh yaitu jika bangsa Jepang sejak duduk di bangku SD sudah ditanamkan nilai-nilai Cinta Tanah Air dan Patriotisme, antara lain melalui hormat dan cinta mereka kepada Sadoko Sasaki, bangsa Indonesia pun sejak dini seyogianya ditanamkan 4 nilai Bela Negara itu (Lesmana, 2016). Diharapkan siswa di Indonesia dapat mencontohkan sikap baik seperti yang dimiliki oleh siswa di Jepang seperti yang sudah disebutkan di atas.

Di Indonesia, kegiatan bela negara menjadi tugas pokok dari menteri pertahanan, sehingga kegiatan bela negara juga diatur dengan sebaik mungkin pada tataran dunia pendidikan. Sebagaimana pendapat yang dikemukakan A Nugroho (2016) Sesuai dengan PERMENHAN No.19/2015 yaitu salah satu bentuk bela negara di dalam pendidikan adalah dikembangkannya kurikulum bela negara mulai TK hingga perguruan tinggi dengan komponen inti adalah mengenal sejarah Indonesia, khususnya sejarah perjuangan merebut dan mempertahankan negara kesatuan Republik Indonesia, program bela negara merupakan program inisiatif kementerian pertahanan, menurut MENHAN bela negara bukan wajib militer, namun sebagai perwujudan hak dan kewajiban negara yang perlu disiapkan.

Hal di atas sejalan dengan peraturan menteri pertahanan No. 19/2015 yang berhubungan tentang penyelenggaraan pertahanan negara untuk periode tahun 20152019 pada bagian "bela negara" tugas dari KEMHAN adalah membantu K/L/Pemda dalam pembinaan kesadaran bela negara dan pembinaan kemampuan pertahanan nonmiliter meliputi kemampuan kewaspadaan dini, kemampuan bela negara, kemampuan diplomasi, kemampuan ilmu pengetahuan dan teknologi, kemampuan ekonomi, kemampuan sosial, kemampuan moral, dan kemampuan (A Nugroho, 2016).

Akan tetapi, semangat bela negara juga dapat ditingkatkan melalui proses pembelajaran pada mata pelajaran Geografi yang terdapat di SMA. Sebelum membahas tentang mata pelajaran geografi, terlebih dahulu akan dibahas tentang pengertian pembelajaran, Bahri (2006:119) Belajar adalah kegiatan yang diproses dan merupakan unsur yang sangat fundamental dalam setiap penyelenggaraan jenis dan jenjang pendidikan, serta suatu proses adaptasi atau penyesuaian tingkah laku yang berlangsung secara progresif. Proses belajar harus melalui jenjang dan tahapannya masing-masing disesuaikan dengan usia atau perkembangan dan pertumbuhan yang dialami oleh siswa. Kemudian, Purwanto (2010:84) Belajar adalah setiap perubahan yang relatif menetap dalam tingkah laku yang terjadi sebagai suatu hasil dari latihan atau pengalaman. Jika ditinjau dari segi afektif, hasil dari setiap proses pembelajaran terlihat pada tingkah laku siswa yang tercermin dalam lingkungan sekolah dan masyarakat.

Proses pembelajaran tidak hanya didapatkan melalui pendidikan yang terdapat di sekolah saja (dibimbing dan dipantau oleh guru), akan tetapi juga didapatkan di dalam lingkungan keluarga (dibimbing oleh kedua orang tua serta semua elemen keluarga), lingkungan masyarakat (dibimbing dan dipantau oleh semua elemen yang terdapat di dalam masyarakat), dan bahkan dari lingkungan alam sekalipun yang akan dibimbing dan dipantau oleh alam itu sendiri. Dan pada akhirnya pendidikan dapat dikategorikan menjadi pendidikan formal, nonformal dan informal.

Sehingga berbagai pengalaman yang diperoleh siswa dari berbagai sumber dapat menjadi pembelajaran yang sangat penting dan sangat berharga di dalam kehidupannya, dan dapat dipastikan apabila pembelajaran yang diperoleh dari pengalaman, pengetahuan tersebut akan bertahan lama dalam ingatan siswa. Rusman (2012:252) Belajar merupakan proses membangun pengetahuan melalui transformasi pengalaman, sedangkan pembelajaran merupakan upaya yang sistemis dan sistematis dalam menata lingkungan belajar guna menumbuhkan dan mengembangkan belajar siswa. Belajar diartikan sebagai aktivitas pengembangan diri melalui pengalaman, bertumpu pada kemampuan diri, belajar di bawah bimbingan pengajar (Tirtarahardja, 2005:51).

Sudjana (1990:57) Belajar adalah suatu proses yang ditandai dengan adanya perubahan 
pada diri seseorang, perubahan sebagai hasil proses belajar dapat ditunjukkan dalam berbagai bentuk seperti berubah pengetahuannya, pemahamannya, sikap dan tingkah lakunya, keterampilannya, kecakapan dan kemampuannya, daya reaksinya, daya penerimaannya, dan lain-lain aspek yang ada pada individu. Dan jika ditinjau dari segi kognitif hasil yang terdapat dari proses pembelajaran terlihat dari pengetahuan yang diperoleh siswa, bagaimana siswa dapat memahami suatu materi pembelajaran, yang dilanjutkan dengan siswa dapat mengkomunikasikan pengetahuannya tersebut kepada orang lain dalam masyarakat dan tercermin pada tingkah laku siswa di dalam lingkungan sekolah dan lingkungan masyarakat.

Nah, dalam pembahasan yang berhubungan dengan meningkatkan semangat bela negara, salah satu proses pembelajarannya yaitu melalui mata pelajaran geografi. Geografi merupakan suatu ilmu pengetahuan yang membahas tentang lingkungan geosfer, yang mana di dalamnya terdiri dari lima unsur yaitu atmosfer (lapisan udara dan sekitarnya) sesuai dengan matra darat, hidrosfer (lapisan air dan sekitarnya) sesuai dengan matra laut, litosfer (lapisan batuan pembentuk bumi yang menjadi tempat tinggal makhluk hidup) sesuai dengan matra darat, biosfer (lapisan makhluk hidup seperti manusia, tumbuhan dan hewan yang saling berinteraksi dalam alam), antroposfer (lapisan masyarakat dan sekitarnya). Bela negara jika di dalam mata pelajaran geografi terdapat pada pembahasan di dalam semua lapisan geosfer yang memiliki hubungan dan kaitannya dengan lapisanlapisan lainnya yang terdapat di dalam lingkungan masyarakat.

Sumaatmadja (1997:12) Hakikat pembelajaran geografi adalah "pengajaran tentang aspek-aspek keruangan permukaan bumi yang merupakan keseluruhan gejala alam dan kehidupan umat manusia dengan variasi kewilayahan". Pasya (2002:85) Geografi mempelajari sesuatu hal yang terdapat di permukaan bumi dengan memilih aspek-aspek yang mempunyai arti penting bagi manusia dalam upaya meningkatkan kelangsungan hidupnya. Geografi telah muncul sebagai suatu disiplin yang berfokus pada interaksi manusia dan lingkungan, geografi memiliki dua pendekatan utama: pertama, adalah ruang yang berfokus pada distribusi fenomena pada suatu area, sementara yang kedua adalah pendekatan yang berkonsentrasi pada perubahan terjadi selama periode waktu (temporal) (Fatima, 2015:43). Maryani (2006:13) Pengajaran geografi harus berorientasi pada (1) permasalahan yang aktual berkembang di sekitar anak didik, (2) kepentingan dan psikologi perkembangan anak didik, (3) peningkatan taraf hidup melalui pengenalan dan pemanfaatan sumberdaya, (4) harus berorientasi ke masa depan, (5) memberikan wawasan global baik dalam bentuk peluang maupun tantangan".

Geografi sebagai suatu ilmu yang ruang lingkup pembahasannya sangat luas, akan tetapi identik dengan aspek keruangan yang terdapat di permukaan bumi. Di dalamnya terdapat interaksi antara makhluk hidup dengan lingkungan sekitar memiliki hubungan timbal balik yang sangat erat antara satu dengan lainnya. Geografi juga membahas permasalahan terkini yang terdapat di dalam masyarakat, yang memiliki kaitan dan hubungannya dengan masa depan, baik itu dalam kekuatan, kelemahan, peluang dan ancaman yang sewaktu-waktu dapat terjadi apabila SDM (sumber daya manusia) di Indonesia tidak siap menghadapi kehidupan di masa yang akan datang.

Di Indonesia mata pelajaran geografi tidak menjadi mata pelajaran wajib yang harus dipelajari oleh semua peserta didik mulai dari jenjang SD/MI, SMP/MTs, SMA/SMK/MA. Hal ini sangat berbeda dengan negara-negara maju lainnya yang ada di dunia, sebagai contoh Inggris, Amerika Serikat, Kanada dan berbagai negara maju lainnya mewajibkan semua peserta didik untuk mempelajari mata pelajaran geografi. Berikut pada tabel 1 akan ditampilkan posisi mata pelajaran geografi di setiap jenjang pendidikan formal negaranegara. 
Tabel 1. Posisi Mata Pelajaran Geografi di Setiap Jenjang Pendidikan Formal Negara-negara

\begin{tabular}{|c|c|c|c|c|}
\hline No. & Negara & $\begin{array}{l}\text { Jenjang Primer } \\
\text { (Primary School) }\end{array}$ & $\begin{array}{c}\text { Menengah Pertama } \\
\text { (Lower Secondary } \\
\text { School) }\end{array}$ & $\begin{array}{c}\text { Menengah Atas } \\
\text { (Upper Secondary } \\
\text { School) } \\
\end{array}$ \\
\hline 1. & Inggris & Geografi Wajib & Geografi Wajib & Pendalaman \\
\hline 2. & $\begin{array}{l}\text { Amerika } \\
\text { Serikat }\end{array}$ & $\begin{array}{l}\text { Geografi masuk } \\
\text { social studies }\end{array}$ & $\begin{array}{l}\text { Diajarkan menjadi sejarah } \\
\text { dan geografi Amerika }\end{array}$ & $\begin{array}{l}\text { Bisa masuk di Science } \\
\text { dan social studies }\end{array}$ \\
\hline 3. & Kanada & $\begin{array}{l}\text { Wajib diajarkan } \\
\text { yakni Canadian } \\
\text { Geography }\end{array}$ & $\begin{array}{l}\text { Wajib diajarkan yakni } \\
\text { canadian geography }\end{array}$ & $\begin{array}{l}\text { Wajib diajarkan yakni } \\
\text { canadian geography }\end{array}$ \\
\hline 4. & Jepang & Masuk social studies & Masuk social studies & $\begin{array}{l}\text { Wajib bersama sejarah, } \\
\text { geografi dan } \\
\text { kewarganegaraan }\end{array}$ \\
\hline 5. & India & - & - & Peminatan \\
\hline 6. & Australia & - & - & $\begin{array}{l}\text { Wajib masuk kelompok } \\
\text { humanities }\end{array}$ \\
\hline 7. & Finlandia & Wajib & $\begin{array}{l}\text { Wajib di dalam kelompok } \\
\text { science }\end{array}$ & $\begin{array}{l}\text { Wajib di dalam } \\
\text { kelompok science } \\
\text { dengan biologi, kimia, } \\
\text { fisika, dan pendidikan } \\
\text { kesehatan }\end{array}$ \\
\hline 8. & Perancis & $\begin{array}{l}\text { Wajib menjadi mapel } \\
\text { sejarah, geografi dan } \\
\text { kewarganegaraan }\end{array}$ & $\begin{array}{l}\text { Wajib menjadi mapel } \\
\text { sejarah dan geografi }\end{array}$ & Pendalaman \\
\hline 9. & Hungaria & - & $\begin{array}{l}\text { Wajib menjadi mapel man } \\
\text { and society; man and } \\
\text { nature; dan our earth and } \\
\text { environment. }\end{array}$ & $\begin{array}{l}\text { Wajib menjadi mapel } \\
\text { man and society; man } \\
\text { and nature; dan our } \\
\text { earth and environment }\end{array}$ \\
\hline 10. & Belanda & - & $\begin{array}{l}\text { Wajib menjadi man and } \\
\text { nature dan man and } \\
\text { society. }\end{array}$ & \\
\hline 11. & $\begin{array}{l}\text { Selandia } \\
\text { Baru }\end{array}$ & - & - & $\begin{array}{l}\text { Geografi masuk ilmu } \\
\text { alam }\end{array}$ \\
\hline 12. & Singapura & - & Geografi Wajib & $\begin{array}{l}\text { Geografi wajib dan } \\
\text { masuk kelompok } \\
\text { humanities }\end{array}$ \\
\hline 13. & Indonesia & Tidak wajib & Tidak wajib & Tidak wajib \\
\hline
\end{tabular}

Berbagai negara maju di dunia menyadari betapa pentingnya mata pelajaran geografi untuk memperkenalkan kondisi alam yang terdapat di negaranya dan di negara lain, serta berbagai fenomena geosfer lainnya yang terjadi di dunia. Sehingga dengan peserta didik mengetahui kondisi alam di negaranya, maka akan dapat meningkatkan rasa cinta kepada negaranya masing-masing. Sehinga tidak heran jikalau peserta didik di Indonesia kurang cinta kepada tanah air dan semangat bela negara yang rendah. Secara tidak langsung berbagai permasalahan tersebut karena pengaruh tidak diwajibkannya mata pelajaran geografi untuk peserta didik mulai dari jenjang SD/MI, SMP/MTs, SMA/SMK/MA di Negara Kesatuan Republik Indonesia.

Melalui artikel ini, terdapat solusi untuk meningkatkan semangat bela negara melalui mata pelajaran geografi. Begitu juga halnya dengan semangat bela negara yang dapat dimasukkan dalam bagian pada setiap materi pelajaran geografi untuk SMA/MA, karena diharapkan dengan mempelajari materi tersebut dapat meningkatkan rasa cinta tanah air dan semangat bela negara pada siswa. Berdasarkan silabus mata pelajaran geografi SMA/MA Kurikulum 2013 Edisi Revisi 2016, 
penulis mencoba untuk menghubungkan

materi geografi dalam menumbuhkan

semangat bela negara dan cinta tanah air siswa.

Tabel 2. Silabus mata pelajaran geografi SMA/MA Kurikulum 2013 Edisi Revisi 2016

\begin{tabular}{|c|c|c|}
\hline \multicolumn{3}{|c|}{ Kelas XI } \\
\hline Kompetensi Dasar & Materi Pembelajaran & Kegiatan Pembelajaran \\
\hline $\begin{array}{l}\text { 3.1 Memahami } \\
\text { kondisi wilayah dan } \\
\text { posisi strategis } \\
\text { Indonesia sebagai } \\
\text { poros maritim dunia. } \\
\text { 4.1 Menyajikan } \\
\text { contoh hasil penalaran } \\
\text { tentang posisi strategis } \\
\text { wilayah Indonesia } \\
\text { sebagai poros maritim } \\
\text { dunia dalam bentuk } \\
\text { peta, tabel, dan/atau } \\
\text { grafik. }\end{array}$ & $\begin{array}{l}\text { POSISI STRATEGIS } \\
\text { INDONESIA SEBAGAI } \\
\text { POROS MARITIM DUNIA } \\
\text { - } \quad \text { Letak, luas, dan batas } \\
\text { wilayah Indonesia. } \\
\text { - Karakteristik wilayah } \\
\text { daratan dan perairan } \\
\text { Indonesia. } \\
\text { - Perkembangan jalur } \\
\text { transportasi dan } \\
\text { perdagangan } \\
\text { internasional di } \\
\text { Indonesia. } \\
\text { Potensi dan pengelolaan } \\
\text { sumber daya kelautan } \\
\text { Indonesia. }\end{array}$ & $\begin{array}{l}\text { Mengamati letak geografis Indonesia } \\
\text { melalui peta dunia. } \\
\text { Berdiskusi tentang letak dan posisi } \\
\text { geografis Indonesia dan kaitannya } \\
\text { dengan poros maritim dunia. } \\
\text { Menyajikan laporan hasil diskusi } \\
\text { tentang posisi strategis Indonesia } \\
\text { sebagai poros maritim dunia } \\
\text { dilengkapi peta, tabel, dan/atau grafik }\end{array}$ \\
\hline $\begin{array}{l}\text { 3.3 Menganalisis } \\
\text { sebaran dan } \\
\text { pengelolaan sumber } \\
\text { daya kehutanan, } \\
\text { pertambangan, } \\
\text { kelautan, dan } \\
\text { pariwisata sesuai } \\
\text { prinsip-prinsip } \\
\text { pembangunan } \\
\text { berkelanjutan. } \\
\text { 4.3 Membuat peta } \\
\text { persebaran sumber } \\
\text { daya kehutanan, } \\
\text { pertambangan, } \\
\text { kelautan, dan } \\
\text { pariwisata di } \\
\text { Indonesia. }\end{array}$ & $\begin{array}{l}\text { PENGELOLAAN } \\
\text { SUMBER DAYA ALAM } \\
\text { INDONESIA } \\
\text { - Klasifikasi sumber daya. } \\
\text { - Potensi dan persebaran } \\
\text { sumber daya alam } \\
\text { kehutanan, } \\
\text { pertambangan, kelautan, } \\
\text { dan pariwisata di } \\
\text { Indonesia. } \\
\text { Analisis Mengenai } \\
\text { Dampak Lingkungan } \\
\text { (AMDAL) dalam } \\
\text { pembangunan. } \\
\text { Pemanfaatan } \\
\text { sumberdaya alam } \\
\text { dengan prinsip-prinsip } \\
\text { pembangunan } \\
\text { berkelanjutan }\end{array}$ & $\begin{array}{l}\text { Mencari informasi tentang sumber } \\
\text { daya kehutanan, pertambangan, } \\
\text { kelautan, dan pariwisata serta } \\
\text { pengelolaannya dari berbagai } \\
\text { sumber/media } \\
\text { Berdiskusi tentang sumber daya } \\
\text { kehutanan, pertambangan, kelautan, } \\
\text { dan pariwisata serta pengelolaannya } \\
\text { sesuai prinsip-prinsip pembangunan } \\
\text { berkelanjutan. } \\
\text { Mengumpulkan dan mengolah } \\
\text { informasi tentang persebaran sumber } \\
\text { daya kehutanan, pertambangan, } \\
\text { kelautan, dan pariwisata serta } \\
\text { pengelolaannya sesuai prinsip-prinsip } \\
\text { pembangunan berkelanjutan } \\
\text { Menyajikan laporan hasil pengolahan } \\
\text { informasi tentang persebaran sumber } \\
\text { daya kehutanan, pertambangan, } \\
\text { kelautan, dan pariwisata serta } \\
\text { pengelolaannya sesuai prinsip-prinsip } \\
\text { pembangunan berkelanjutan } \\
\text { dilengkapi peta }\end{array}$ \\
\hline $\begin{array}{l}\text { 3.4 Menganalisis } \\
\text { ketahanan pangan } \\
\text { nasional, penyediaan } \\
\text { bahan industri, serta } \\
\text { potensi energi baru }\end{array}$ & $\begin{array}{l}\text { KETAHANAN PANGAN, } \\
\text { INDUSTRI DAN ENERGI } \\
\text { - Pengertian ketahanan } \\
\text { pangan, bahan industri, } \\
\text { serta energi baru dan } \\
\text { terbarukan. }\end{array}$ & $\begin{array}{l}\text { Mencari informasi tentang sumber } \\
\text { daya kehutanan, pertambangan, } \\
\text { kelautan, dan pariwisata serta } \\
\text { pengelolaannya dari berbagai } \\
\text { sumber/media. }\end{array}$ \\
\hline
\end{tabular}




\begin{tabular}{|c|c|c|}
\hline \multicolumn{3}{|c|}{ Kelas XI } \\
\hline Kompetensi Dasar & Materi Pembelajaran & Kegiatan Pembelajaran \\
\hline $\begin{array}{l}\text { dan terbarukan di } \\
\text { Indonesia. } \\
4.4 \text { Membuat peta } \\
\text { persebaran ketahanan } \\
\text { pangan nasional, } \\
\text { bahan industri, serta } \\
\text { energi baru dan } \\
\text { terbarukan di } \\
\text { Indonesia. }\end{array}$ & $\begin{array}{l}\text { Potensi dan persebaran } \\
\text { sumber daya pertanian, } \\
\text { perkebunan, perikanan, } \\
\text { dan peternakan untuk } \\
\text { ketahanan pangan } \\
\text { nasional. } \\
\text { Potensi dan persebaran } \\
\text { sumber daya untuk } \\
\text { penyediaan bahan } \\
\text { industri. } \\
\text { Potensi dan persebaran } \\
\text { sumber daya untuk } \\
\text { penyediaan energi baru } \\
\text { dan terbarukan. } \\
\text { Pengelolaan sumber } \\
\text { daya dalam penyediaan } \\
\text { bahan pangan, bahan } \\
\text { industri, serta energi } \\
\text { baru dan terbarukan di } \\
\text { Indonesia. }\end{array}$ & $\begin{array}{l}\text { Berdiskusi tentang sumber daya } \\
\text { kehutanan, pertambangan, kelautan, } \\
\text { dan pariwisata serta pengelolaannya } \\
\text { sesuai prinsip-prinsip pembangunan } \\
\text { berkelanjutan. } \\
\text { Mengumpulkan dan mengolah } \\
\text { informasi tentang persebaran sumber } \\
\text { daya kehutanan, pertambangan, } \\
\text { kelautan, dan pariwisata serta } \\
\text { pengelolaannya sesuai prinsip-prinsip } \\
\text { pembangunan berkelanjutan. } \\
\text { Menyajikan laporan hasil pengolahan } \\
\text { informasi tentang persebaran sumber } \\
\text { daya kehutanan, pertambangan, } \\
\text { kelautan, dan pariwisata serta } \\
\text { pengelolaannya sesuai prinsip-prinsip } \\
\text { pembangunan berkelanjutan } \\
\text { dilengkapi peta }\end{array}$ \\
\hline
\end{tabular}

Sumber: Kementrian Pendidikan dan Kebudayaan (2016)

Menurut hemat penulis, ada tiga materi penting pada mata pelajaran geografi yang dapat menumbuhkan semangat bela negara siswa, diantaranya yaitu sebagai berikut: materi pertama: posisi strategis Indonesia sebagai poros maritim dunia, di dalamnya akan mempelajari tentang (1) Letak, luas, dan batas wilayah Indonesia. (2) Karakteristik wilayah daratan dan perairan Indonesia. (3) Perkembangan jalur transportasi dan perdagangan internasional di Indonesia. (4) Potensi dan pengelolaan sumber daya kelautan Indonesia.

Materi kedua: pengelolaan sumber daya alam Indonesia, di dalamnya akan mempelajari tentang (1) Klasifikasi sumber daya. (2) Potensi dan persebaran sumber daya alam kehutanan, pertambangan, kelautan, dan pariwisata di Indonesia. (3) Analisis Mengenai Dampak Lingkungan (AMDAL) dalam pembangunan. (4) Pemanfaatan sumberdaya alam dengan prinsip-prinsip pembangunan berkelanjutan. Materi ketiga: ketahanan pangan, industri dan energi di dalamnya akan mempelajari tentang (1) Pengertian ketahanan pangan, bahan industri, serta energi baru dan terbarukan. (2) Potensi dan persebaran sumber daya pertanian, perkebunan, perikanan, dan peternakan untuk ketahanan pangan nasional. (3) Potensi dan persebaran sumber daya untuk penyediaan bahan industri. (4) Potensi dan persebaran sumber daya untuk penyediaan energi baru dan terbarukan. (5) Pengelolaan sumber daya dalam penyediaan bahan pangan, bahan industri, serta energi baru dan terbarukan di Indonesia.

Diharapkan setelah mempelajari ketiga materi di atas, membuat siswa semakin bertambah rasa cintanya terhadap Negara Kesatuan Republik Indonesia. Hal tersebut dikarenakan siswa telah menyadari betapa luasnya Indonesia baik di daratan maupun di lautan. Kemudian, tidak hanya dari segi luasnya saja akan tetapi ditambah lagi dengan potensi sumber daya kelautan Indonesia yang begitu besar, maka sangat wajar jika diprediksi apabila semua potensi sumber daya kelautan Indonesia dapat dimanfaatkan dengan baik oleh masyarakat, hal itu akan berdampak baik terhadap meningkatnya perekonomian dan taraf kesejahteraan masyarakat khususnya yang berprofesi sebagai nelayan dan berbagai profesi lainnya yang memanfaatkan lautan sebagai lahan pekerjaan. Dan juga nantinya hasil dari pengolahan sumber daya kelautan tersebut dapat diekspor ke luar negeri dan 
dimanfaatkan dengan baik oleh seluruh masyarakat Indonesia. Sumber daya kelautan juga memiliki kandungan protein yang sangat besar dan baik untuk kesehatan, sehingga akan berdampak terhadap meningkatknya taraf kesehatan dan juga dapat mencerdaskan generasi-generasi muda di masa yang akan datang.

Indonesia tidak hanya kaya akan sumber daya lautan saja, akan tetapi Indonesia juga memiliki kekayaan sumber daya alam sangat melimpah terdapat di daratan, hal ini sangat dipengaruhi dengan letak geologis dan letak geomorfologis Indonesia, yang berada di antara tiga lempeng besar di dunia yaitu lempeng Indo-Australia, lempeng Eurasia dan lempeng Pasifik yang berdampak terhadap Indonesia rawan akan bencana alam gempa bumi dan tsunami. Setelah itu, Indonesia juga dipengaruhi dengan dilalui oleh cincin api (ring of fire) dunia sehingga menyebabkan di Indonesia terdapat banyak gunung api aktif di dunia. Akan tetapi, dibalik dampak negatif tersebut menyimpan berjuta hikmah dan dampak positif lainnya untuk seluruh masyarakat, Indonesia menjadi negara yang sangat subur dari segi keadaan tanah sebagai contoh sumber daya pertanian, perkebunan, perikanan, dan peternakan, yang mana semua sumber daya tersebut sangat penting dan bermanfaat bagi masyarakat untuk ketahanan pangan nasional, sehingga menghindari Indonesia dari kekurangan akan kebutuhan pokok yang dapat berakibat kepada bencana kelaparan dan kekurangan gizi.

Kemudian, Indonesia juga kaya dari segi keadaan akan sumber daya alam yang dimilikinya, sebagai contoh sumber daya alam kehutanan, pertambangan, dan pariwisata di Indonesia. semua sumber daya alam di atas apabila dimanfaatkan dengan baik oleh pemerintah dan masyarakat, maka dapat dipastikan Indonesia akan menjadi negara maju, makmur dan kaya akan keuangan yang berasal dari kekayaan sumber daya alamnya. Dan juga ditambah dengan siswa mengingat kembali bagaimana susahnya pahlawanpahlawan kemerdekaan Indonesia pada zaman dahulu yang telah mengorbankan jiwa dan raganya dalam rangka merebut dan meraih kemerdekaan Indonesia yang seutuhnya dan sesungguhnya pada 17 Agustus 1945.
Peranan dan kontribusi guru mata pelajaran geografi sangat dibutuhkan dalam rangka penyampaian materi-materi di atas dengan sangat baik, diharapkan guru dapat mengajarkan semua materi tersebut dengan menggunakan berbagai pendekatan, metode, model dan media pembelajaran yang dapat membangkitkan semangat belajar siswa.

Intinya, konsep TCB (Tau, Cinta dan Bela) saling berhubungan antara satu dengan lainnya, peserta didik tidak akan mau untuk membela negara Indonesia, apabila peserta didik tidak cinta akan tanah air, peserta didik tidak cinta tanah air karena tidak tau seutuhnya dengan Negara Republik Indonesia. Setelah peserta didik mengetahui dan mengenal Indonesia seutuhnya, selanjutnya akan tumbuh rasa cinta tanah air dengan sendirinya, setelah terdapat rasa cinta tanah air dalam jiwa peserta didik, pada akhirnya akan tumbuh dengan sendirinya rasa bela negara dalam jiwa peserta didik. Sehingga akan berdampak terhadap kesadaran siswa dalam rangka mempertahankan, menjaga dan melindungi seluruh wilayah Indonesia dari Sabang sampai Merauke, dari Pulau Talaud sampai Pulau Rote.

Dengan demikian, pada akhirnya diharapkan rasa cinta akan tanah air dan semangat bela negara siswa dapat meningkat, sehingga siswa tidak ingin apabila ada sejengkal dari wilayah Indonesia yang dijajah dan dikuasai oleh negara lain, sehingga siswa dapat dengan serius dan sungguh-sungguh dalam mempertahankan, menjaga dan melindungi Negara Kesatuan Republik Indonesia agar tidak dijajah dan dikuasai oleh negara lain yang ingin memiliki Negara Indonesia karena kaya akan sumber daya alam yang dimilikinya. Berdasarkan pembahasan di atas, maka sudah sangat jelas jikalau rasa semangat bela negara dan cinta tanah air dapat ditumbuhkan dan ditingkatkan melalui pembelajaran yang terdapat di dalam mata pelajaran Geografi khususnya di tingkat SMA/MA.

\section{SIMPULAN}

Bela negara menjadi kewajiban setiap warga negara, bela negara pada siswa di SMA/MA dapat ditumbuhkan melalui mata pelajaran geografi sebagaimana yang 
dituangkan dalam kurikulum, terdapat beberapa materi pelajaran yang memberikan kontribusi terhadap meningkatkan semangat bela negara terutama di kelas XI. Namun demikian, sangat penting profesionalitas guru dalam membelajarkan siswa agar terbentuk rasa cinta tanah air yang dapat diwujudkan dalam bentuk semangat bela negara. Apabila sewaktu-waktu dibutuhkan kontribusi siswa dalam rangka mempertahankan, menjaga dan melindungi kemerdekaan serta seluruh wilayah Indonesia baik yang berada di daratan maupun di lautan. Jadi, dapat disimpulkan jikalau mata pelajaran geografi berkontribusi besar dan penting dalam rangka meningkatkan semangat bela negara siswa SMA/MA di Provinsi Aceh.

\section{DAFTAR PUSTAKA}

A Nugroho, Riant. 2016. Bela Negara Dalam Perspektif Kebijakan Publik. Wira: Media Informasi Kementrian Pertahanan. Jakarta: Puskom Publik Kemhan.

Amanda, Gita. 2017. HNW: Bela Negara Penting untuk Landasan Sikap dan Perilaku. Sabtu , 18 November 2017, 09:44 WIB. Diakses dari http://www.republika.co.id/berita/mprri/berita-mpr/17/11/18/ozle9o423-

hnw-bela-negara-penting-untuklandasan-sikap-dan-perilaku. Diakses pada Hari Minggu, 19 November 2017 Pukul 10.30.

Bahri, Agus. 2006. Cooperative Learning Teori dalam Aplikasi Paikem. Yogyakarta: Pustaka Pelajar.

Basri, Yusman (ed.), 1982. Sejarah Nasional Indonesia, Jilid V. Jakarta : Departemen Pendidikan dan Kebudayaan Direktorat Sejarah dan Nilai Tradisional.

Fatima, Munazza, Sajid Noor, Adila Shaqifat. (2015). An Overview of Geography Education in Pakistan. Turkish Journal of Geography Education, 1(2): 43-53. ISSN: 2149-522X.

Hadi, Yulianto. Suryo, Djoko. Sudarsono, F.X. 2014. Dinamika Penanaman NilaiNilai Bela Negara Kadet Maguwo Dalam Perspektif Historis. Jurnal Pembangunan Pendidikan: Fondasi dan
Aplikasi Volume 2, Nomor 2, 2014 Jurnal Pembangunan dan Pendidikan: Fondasi dan Aplikasi.

Hardjosatoto, S. (1985). Sejarah Pergerakan Nasional Indonesia, Suatu Analisis Ilmi-Ah. Yogyakarta: Liberty.

Jayanti, Kurnia. 2010. Konflik Vertikal Antara Gerakan Aceh Merdeka dengan Pemerintah Pusat di Jakarta Sejak 1976-2005. Jakarta: Universitas Negeri Islam Syarif Hidayatullah Jakarta.

Kardono, Priyadi. Hartono. Suprajaka. 2015. Paradigma Geomaritim (Strategi Mewujudkan Indonesia Sebagai Poros Maritim Dunia dalam Perspektif Geografi. Bogor: Badan Informasi Geospasial

Kementrian Pendidikan dan Kebudayaan. 2016. Silabus Mata Pelajaran Geografi Sekolah Menengah Atas/ Madrasah Aliyah Kurikulum 2013 Edisi Revisi. Jakarta: Kemendikbud.

Lesmana, Tjipta. 2016. Bela Negara Dan Ancaman Budaya Kekerasan. Wira: Media Informasi Kementrian Pertahanan. Jakarta: Puskom Publik Kemhan.

Maharani, Esti. 2015. MENHAN: Bela Negara Bangsa Indonesia Rendah Sekali. Republika. Sabtu , 28 Maret 2015, 19:17 WIB. Diakses dari http://nasional.republika.co.id/berita/n asional/politik/15/03/28/nlx8t5menhan-bela-negara-bangsaindonesia-rendah-sekali. Diakses pada Hari Minggu, 19 November 2017 Pukul 10.30.

Maharani, Esti. 2015. Prabowo Subianto: Bela Negara Penting. Kamis, 22 Oktober 2015, 17:58 WIB. Diakses dari http://nasional.republika.co.id/berita/n asional/politik/15/03/28/nlx8t5menhan-bela-negara-bangsaindonesia-rendah-sekali. Diakses pada Hari Minggu, 19 November 2017 Pukul 10.30.

Maruapey, M Husein. 2016. Pajak Dan Bela Negara. Jurnal Ilmu Politik dan Komunikasi Volume VI No. 1 / Juni 2016.

Maryani, Enok. (2006). Kontribusi Pendidikan Geografi Dalam Mengembangkan 
Modal Sosial Untuk Menuju

Keunggulan Berbangsa dan

Bernegara. Makalah disajikan dalam Seminar Nasional IPS di Bandung 5 Agustus 2006.

Pasya, Gunirwan Kamil. (2002). Geografi Pemahaman Konsep dan Metodologi. Bandung: Penerbit Buana Nusantara.

Purwanto, Ngalim. 2007. Ilmu Pendidikan Teoretis dan Praktis. Bandung: PT. Remaja Rosdakarya.

Rusman. 2012. Model-Model Pembelajaran. Jakarta: PT Raja Grafindo Persada.

Saifuddin, Fedyani Achmad. 2016. Strategi Sosial Budaya Bagi Bela Negara: Suatu Perbincangan Konseptual. Wira: Media Informasi Kementrian Pertahanan. Jakarta: Puskom Publik Kemhan.
Sudjana. 1990. Penilaian Hasil Proses Belajar Mengajar. Bandung: PT. Remaja Rosda karya.

Sumaatmadja. (1997). Metodologi Pengajaran Geografi. Jakarta : Bumi Aksara.

Sutarman, Ws. 2011. Persepsi Dan Pengertian Pembelaan Negara Berdasarkan UUD 1945 (Amandemen). Magistra No. 75 Th. XXIII Maret 2011 77. ISSN 02159511.

Thoha, Ahmad. 2004. Evaluasi Pendidikan. Bandung: PT. Remaja Rosdakarya.

Tippe, Syarifudin. 2013. Implementasi Kebijakan Bela Negara Di Perbatasan : Studi Kasus Di Provinsi Papua. Jurnal Sosioteknologi Edisi 29 Tahun 12, Agustus 2013. 